Article

\title{
Performance and Microbial Diversity in a Low-Energy ANF-WDSRBC System for the Post-Treatment of Decentralized Domestic Wastewater
}

\author{
Juanhong Li and Xiwu Lu* \\ School of Energy and Environment, Southeast University, Nanjing 210096, China; Li_juanhong1@163.com \\ * Correspondence: xiwulu@seu.edu.cn; Tel.: + 86-25-8379-2614 \\ Academic Editor: Andreas N. Angelakis \\ Received: 18 February 2017; Accepted: 28 April 2017; Published: 6 May 2017
}

\begin{abstract}
Recently, more decentralized wastewater treatments are of great interest for rural regions. In this work, a novel ANF-WDSRBC system combined with an anoxic filter (ANF) and a four-stage water-dropping-self-rotating biological contactor (WDSRBC) was designed as a post-treatment option. With a total hydraulic retention time (HRT) of $8.8 \mathrm{~h}$ and reflux ratio of 1:1, the ANF-WDSRBC system was operated 160 days. The results showed the ANF-WDSRBC system had better performance without mechanical aeration devices, the removal efficiencies of chemical oxygen demand (COD), ammonia $\left(\mathrm{NH}_{4}{ }^{+}-\mathrm{N}\right)$ and total nitrogen $(\mathrm{TN})$ were $61.4 \% \pm 4.3 \%, 86.1 \% \pm 3.7 \%$, and $54.5 \% \pm 3.9 \%$, respectively. By means of high-throughput MiSeq sequencing, the results suggested that Proteobacteria, Bacteroidetes, Firmicutes, and Chloroflexi were the predominant phyla in the system. In the WDSRBC units, Nitrosomonas, Nitrosospira, Bacillus, and Nitrospira were the main genera to take part in nitrification. Longilinea, Bellilinea, Thiobacillus, and Thauera in the ANF unit were the main genera to participate in denitrification and organic matters degradation. The novel ANF-WDSRBC system had great potential in the post-treatment of decentralized domestic wastewater.
\end{abstract}

Keywords: decentralized domestic wastewater; ANF-WDSRBC; nitrification; denitrification; high-throughput MiSeq sequencing

\section{Introduction}

In recent years, more and more attention has been focused on the treatment of decentralized domestic wastewater by anaerobic techniques in developing countries, particularly in the rural areas of China [1-4]. That may be attributed to the energy recovery and low sludge production in anaerobic bioreactors [1-3]. Despite of these advantages, anaerobic techniques are not widely adopted due to the lack of nitrogen removal capability [4-7]. Even though nitrogen is one of the important nutrients for agriculture and landscaping irrigation reuse [8], nitrogen also plays a major role in oxygen depletion and eutrophication in the receiving water bodies [9]. Therefore, it is necessary to reduce nitrogen concentration of the decentralized domestic wastewater and polish up the effluent of anaerobic reactors using a post-treatment system.

It was reported that aerated filters [10], water-dropping aeration submerged biofilm reactor (WDABR) [4], aerobic membrane bioreactor (MBR) [6,7], stabilization ponds [11], and constructed wetlands (CW) $[12,13]$ had been applied in decentralized domestic wastewater treatment. Nevertheless, there still have many challenges, such as high energy consumption in aerobic systems, low organic load rate, flow clogging of constructed wetlands and high land footprint of stabilization ponds existed during the whole process. Rotating biological contactors (RBCs) are cost-effective and flexible attached growth bioreactors, which are widely used to treat various wastewater including domestic wastewater [14-17], dye wastewater [18], and landfill leachate [19]. The RBCs are fascinating options 
to decentralized wastewater treatment due to high specific surface area, high biomass content, low footprint, and easy operation [20]. Even though RBCs are mostly reliable, they still have some shortcomings in terms of costs and stable nitrogen removal efficiency. Compared to constructed wetlands and water-dropping aeration submerged biofilm reactors, RBCs had higher ammonium removal efficiency but higher energy costs $[4,21]$.

In order to further save the energy costs and improve the performance of RBCs, great effort has been spent on modifying RBCs configuration, such as self-rotating discs [22,23], net-like rotating biological contactor [24], and RBC-MFC [25]. Self-rotating discs (SRDs) are cost-effective devices to improve the self-purification efficiency of water stream via increasing dissolved oxygen in the water stream with natural mechanical energy of rivers [22]. Although SRDs has been proven efficient in river self-purification, there is a little information about the application of SRDs on treating decentralized domestic wastewater.

Microbial communities are the main drivers of biological wastewater treatment. Knowledge regarding the microbial consortia in biological systems is of great importance for comprehensive understanding the performance and stability of biological reactors [26,27]. In recent years, molecular biology tools have been widely developed to determine the microbial communities in the wastewater treatment $[15,25,26]$. It is necessary to identify the microbial compositions and structures of novel biological reactors by this way. Currently, high-throughput sequencing technology is becoming one of the efficient molecular tools for analyzing the microbial diversity. However, there is no study focused on the relationship between microbial communities and nitrogen removal in the SRD system.

To overcome these aforementioned challenges, based on the SRD device configuration, we explored a modified Anoxic/Oxic (A/O) process of an anoxic filter (ANF) and four-stage water-dropping-self-rotating biological contactor (WDSRBC) as an alternative post-treatment. In this system, the ANF unit packed with wool-felt was mainly used for COD removal and denitrification with WDSRBC effluent reflux. The WDSRBC units were used for nitrification via natural mechanical energy of wastewater. Unlike the traditional A/O activated sludge process with complex mechanical mixing devices in the anoxic unit, this system enhanced denitrification for nitrogen removal in the ANF unit with packing wool-felt carrier. The wool-felt carriers were suitable for deploying high biomass and reducing washout of biomass. Without mechanical aeration devices in the oxic unit for improving oxygen transfer capacity and nitrification, the WDSRBC units are more energy-efficient than traditional RBC, MBR [7], and aeration filter [10] due to water-dropping gravity rotation.

The aim of this study was to evaluate the performance of the ANF-WDSRBC system in treating decentralized domestic wastewater. Moreover, high-throughput MiSeq sequencing was used to determine the compositions and structures of microbial communities in each unit of the system.

\section{Materials and Methods}

\subsection{Experimental Setup}

Figure 1 shows the schematic diagram of the experimental set-up of the ANF-WDSRBC system. The system consisted of an anoxic filter and a four-stage WDSRBC made of PVC sheets. The ANF $(\varnothing 150 \mathrm{~mm} \times 1500 \mathrm{~mm})$ packed with vertical wool-felt carriers had a $25 \mathrm{~L}$ effective volume. Each WDSRBC unit $(350 \mathrm{~mm} \times 200 \mathrm{~mm} \times 150 \mathrm{~mm})$ had a $7.5 \mathrm{~L}$ effective volume and 15 discs with $150 \mathrm{~mm}$ diameter. The discs of WDSRBC were $40 \%$ submerged. The water-dropping height between each WDSRBC was $0.6 \mathrm{~m}$. The wastewater first pumped through the ANF and then drained to the WDSRBC. In order to utilize the carbon source from wastewater to enhance TN removal, the effluent of WDSRBC was partially recycled to the ANF, serving as a nitrate source. The remaining effluent of the WDSRBC was drained to the wetland for irrigation. 

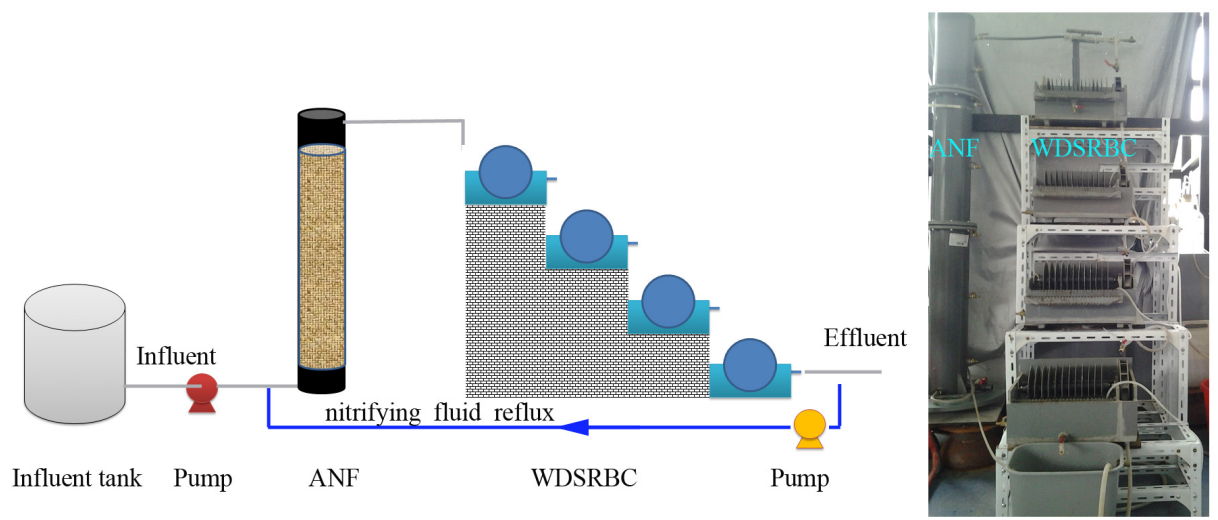

Figure 1. Schematic diagram and photos of the ANF-WDSRBC system.

\subsection{Wastewater Characteristics and Seeding Sludge}

The ANF-WDSRBC system wastewater was the effluent of the anaerobic filter reactor that treated domestic wastewater obtained from Southeast University located in Wuxi, China. The main characteristics of the influent of the ANF-WDSRBC system are presented in Table 1. The seeding sludge used in the study was received from an aeration unit of a WWTP located at Wuxi city in China. The initial MLSS and MLVSS concentrations of seeding sludge were $3000 \mathrm{mg} / \mathrm{L}$ and $4000 \mathrm{mg} / \mathrm{L}$, respectively.

Table 1. Main characteristics of the influent of the ANF-WDSRBC system.

\begin{tabular}{ccccccc}
\hline pH & COD (mg/L) & $\begin{array}{c}\mathrm{NH}_{4}{ }^{+}-\mathrm{N} \\
(\mathrm{mg} / \mathrm{L})\end{array}$ & $\begin{array}{c}\mathrm{NO}_{3}{ }^{-}-\mathrm{N} \\
(\mathrm{mg} / \mathrm{L})\end{array}$ & $\begin{array}{c}\mathrm{NO}_{2}{ }^{-}-\mathrm{N} \\
(\mathrm{mg} / \mathrm{L})\end{array}$ & $\mathrm{TN}(\mathrm{mg} / \mathrm{L})$ & DO (mg/L) \\
\hline $7.1 \pm 0.2$ & $91.4 \pm 21.0$ & $26.7 \pm 5.5$ & $0.37 \pm 0.2$ & $\mathrm{ND}^{*}$ & $37.6 \pm 7.1$ & $0.20 \pm 0.03$ \\
\hline \multicolumn{7}{c}{${ }^{*}$ where, ND: not detect. }
\end{tabular}

\subsection{Analytical Methods}

\subsubsection{Chemical Analysis}

Concentrations of $\mathrm{COD}, \mathrm{NH}_{4}{ }^{+}-\mathrm{N}, \mathrm{NO}_{3}{ }^{-}-\mathrm{N}$ and $\mathrm{TN}$ were measured according to the standard method [28]. Dissolved oxygen (DO) and $\mathrm{pH}$ were measured with a DO meter (YSI-DO200, YSI, Yellow Springs, OH, USA) and a pH meter (YSI-pH100, YSI, Yellow Springs, OH, USA).

\subsubsection{Microbial Community Analysis by MiSeq Sequencing}

In order to study the complete microbial community structures, biofilm samples were collected from each unit (namely ANF, WDSRBC1, WDSRBC2, WDSRBC3, and WDSRBC4) of the system on day 160. The total DNA was extracted using OMEGA Soil DNA Kit D5625-01(Omega Bio-Tek, Norcross, GA, USA) according to the manufacturer's protocol. The quality and quantity of the extracted DNA was measured by a Nanodrop 1000 spectrophotometer (NanoDrop Technologies, Wilmington, DE, USA).

The V3-V4 region of bacterial 16S rRNA genes was amplified using primers 319F/806R (5'-ACTCCTACGGGAGGCAGCAG-3' /5'-GGACTACHVGGGTWTCTAAT-3'). PCR reactions were carried out in $25 \mu \mathrm{L}$ mixture contained $25 \mathrm{ng}$ template DNA, $2.5 \mu \mathrm{L}$ forward and reverse primer $(1 \mu \mathrm{M})$, and $12.5 \mu \mathrm{L}$ Premix Ex TaqTM Hot Start Version (Takara Bio Inc., Shiga, Japan). Amplification was performed under the following conditions: initial denaturing for $30 \mathrm{~s}$ at $98{ }^{\circ} \mathrm{C}$, followed by 30 cycles of $10 \mathrm{~s}$ at $98^{\circ} \mathrm{C}, 30 \mathrm{~s}$ at $56^{\circ} \mathrm{C}, 45 \mathrm{~s}$ at $72{ }^{\circ} \mathrm{C}$, and a final extension step of 10 min elongation at $72{ }^{\circ} \mathrm{C}$. The PCR products were confirmed by $2 \%$ agarose gel electrophoresis and purified using 
the AxyPrepDNA Gel Extraction Kit (Axygen, Union City, CA, USA) following the manufacturer's protocol. At last, the purified amplicons were pooled in equimolar and paired-end sequenced using the Illumina-MiSeq platform (Illumina Inc., San Diego, CA, USA). After removing the short and low-quality reads, Illumina-Miseq sequencing analysis obtained 90782 effective sequences for five samples. The resulting high-quality sequences were clustered into operation taxonomic units (OTU) at $97 \%$ similarity level by Mothur. Representative sequences selected for each OTU were assigned a taxonomy using a Ribosomal Database Project (RDP) classifier with a confidence threshold of $80 \%$.

\section{Results and Discussion}

\subsection{Nitrogen Removal of the ANF-WDSRBC System at Different Reflux Ratios}

Previous studies have been reported the impact of reflux ratio on TN removal in various reactors $[4,29,30]$. Hiras et al. [14] showed that TN removal efficiency increased up to a reflux ratio of $300 \%$ in a two-stage rotating biological contactor. Chiou et al. [29] found that the maximum TN removal efficiency in a pre-denitrification/nitrification biofilter occurred at a reflux ratio of $250 \%$. Our previous study [4] demonstrated the ABR-WDASB system achieved high nitrogen removal efficiency at a reflux ratio of $100 \%$. Based on these previous studies, considering the influent concentrations of COD and TN, the ANF-WDSRBC system started its operation at three different reflux ratios $(50 \%$, $100 \%$, and $200 \%$ ) to treat decentralized domestic wastewater.

As shown in Figure 2, the average nitrogen removal efficiencies of the reflux ratios 50\%, 100\%, and $200 \%$ were $31.4 \% \pm 5.7 \%, 52.9 \% \pm 2.8 \%$, and $54.5 \% \pm 2.8 \%$, respectively. It indicated that $\mathrm{TN}$ removal efficiency increased when reflux ratio increased. This result was consistent with our previous study using the ABR-WDASB system to treat rural domestic wastewater [4]. It was also shown that the reflux ratio ranging from $50 \%$ to $100 \%$ had a significant promote effect on $\mathrm{TN}$ removal efficiency than that of from $100 \%$ to $200 \%$. Although denitrification in the ANF unit depended on the amount of returned nitrifying solution, a high reflux ratio might increase the returned nitrifying solution and enhance TN removal [29], but it is not cost-effective due to high energy consumption. Hence, a cost-effective reflux ratio of $100 \%$ was chosen for the system operation.

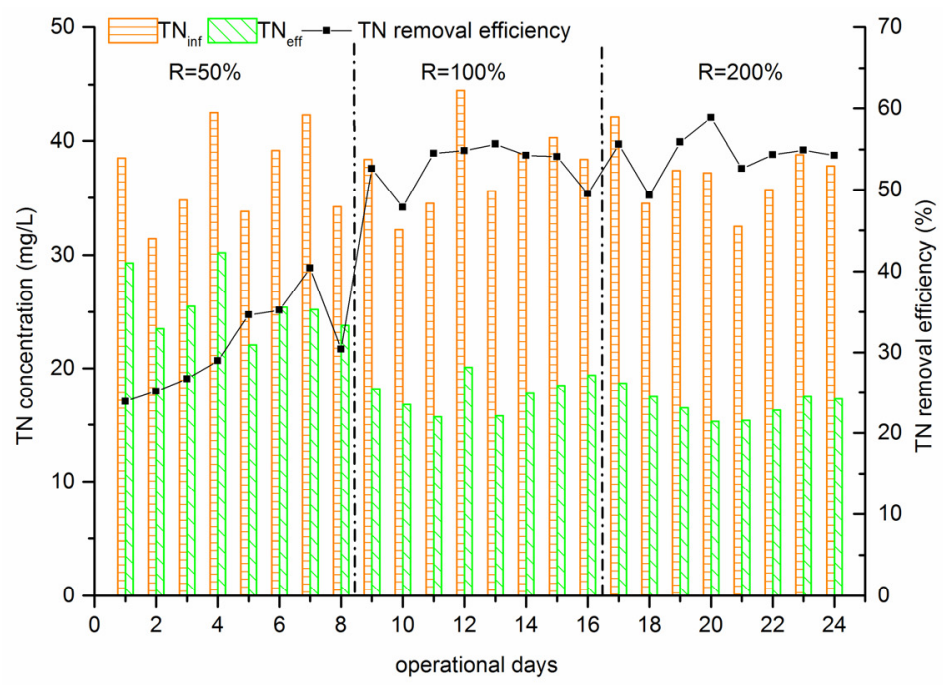

Figure 2. Effects of reflux ratios (R) on the TN removal efficiencies.

\subsection{Performance of the ANF-WDSRBC System at Steady State}

In order to evaluate the performance of the system at steady state condition, the ANF-WDSRBC system was operated as a continuous flow with a stable flow of $150 \mathrm{~L} /$ day (The reflux ratio 1:1). The performance of the system in terms of COD, ammonia, nitrate, nitrite, and TN are shown in Figure 3 
(over time) and Table 2 (in average). Throughout the whole operation, the system was operated with a total HRT $8.8 \mathrm{~h}$ (ANF $4 \mathrm{~h}$, WDSRBC $4.8 \mathrm{~h}$ ) for 160 days. Even though the influent concentration of COD was fluctuated in range of $54.2-147.4 \mathrm{mg} / \mathrm{L}$, the effluent concentration of COD remained stable, resulting in the total average COD removal efficiency of $61.4 \% \pm 4.3 \%$, which was higher than previous reports for aerated fixed bed ( $47.6 \%$ of COD removal) treating the effluent of UASB [31]. For the ANF unit, the average COD removal efficiency was $43.0 \% \pm 4.0 \%$, while the effluent COD concentration was $51.6 \pm 10.4 \mathrm{mg} / \mathrm{L}$. In contrast, the COD removal efficiency was $18.3 \% \pm 3.3 \%$ for the four-stage WDSRBC, and the final effluent COD concentration was $35.0 \pm 7.7 \mathrm{mg} / \mathrm{L}$. Among these reactors of the system, it was remarkably observed that ANF was the predominant contributor in COD removal with the WDSRBC effluent recirculation.
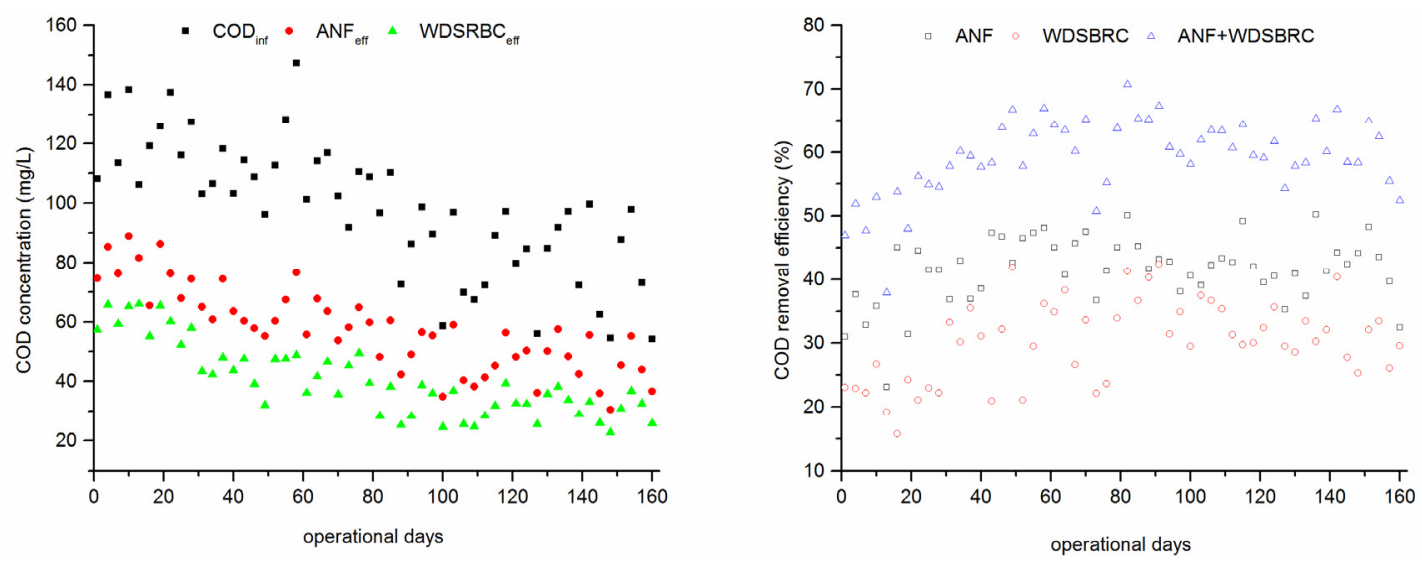

Figure 3. Influent, effluent, and removal efficiency of COD throughout the whole operation.

Table 2. Summary of the ANF-WDSRBC process performances.

\begin{tabular}{ccccccc}
\hline Unit (mg/L) & $\mathbf{C O D}$ & $\mathbf{N H}_{4}{ }^{+}-\mathbf{N}$ & $\mathbf{N O}_{3}{ }^{-}-\mathbf{N}$ & $\mathbf{N O}_{2}{ }^{-}-\mathbf{N}$ & $\mathbf{T N}$ & DO \\
\hline Influent & $91.4 \pm 21.0$ & $26.7 \pm 5.5$ & $0.37 \pm 0.2$ & $\mathrm{ND}^{\#}$ & $37.6 \pm 7.1$ & $0.20 \pm 0.03$ \\
ANF & $51.6 \pm 10.4$ & $22.3 \pm 4.4$ & $1.01 \pm 0.5$ & $\mathrm{ND}^{\#}$ & $23.8 \pm 5.5$ & $0.35 \pm 0.02$ \\
Four-stages & $35.0 \pm 7.7$ & $3.7 \pm 1.1$ & $12.6 \pm 3.4$ & $0.23 \pm 0.18$ & $17.1 \pm 4.2$ & $5.15 \pm 0.05$ \\
WDSRBC & $61.4 \pm 4.3$ & $86.1 \pm 3.7$ & - & - & $54.5 \pm 3.9$ & - \\
$\operatorname{Re}^{*}(\%)$ & & & - &
\end{tabular}

\# where, ND: not detect; * where, Re: Removal efficiency.

Figure 4 shows the variation of ammonia concentration in the influent and effluent of each unit during 160 days' operation. When the influent concentration of ammonia varied from 13.9 to $40.6 \mathrm{mg} / \mathrm{L}$ with an average value of $26.7 \mathrm{mg} / \mathrm{L}$, the effluent ammonia concentration of the system basically stabilized at $3.7 \pm 1.1 \mathrm{mg} / \mathrm{L}$, corresponding to the average ammonia removal efficiency of $86.1 \% \pm 3.7 \%$. Compared with the COD removal in the ANF-WDSRBC system, the total removal efficiency of ammonia was much higher, indicating that the activity of ammonium oxidation bacteria in the system was high during the whole operation period. Along the flowpaths of the system, the effluent concentration of ammonia decreased from $22.3 \pm 4.4 \mathrm{mg} / \mathrm{L}$ in ANF unit to $16.9 \pm 4.0 \mathrm{mg} / \mathrm{L}$ (WDSRBC1), $8.3 \pm 1.7 \mathrm{mg} / \mathrm{L}$ (WDSRBC2), $6.8 \pm 1.2 \mathrm{mg} / \mathrm{L}$ (WDSRBC3), and $3.7 \pm 1.1 \mathrm{mg} / \mathrm{L}$ (WDSRBC4), respectively. WDSRBC1 played a pivotal role in the ammonia removal. It might be due to the fact that the influent concentration of COD in the WDSRBC1 was much lower, favoring the nitrifying biomass growth [32]. Previous studies $[4,33]$ reported that ammonia was always removal via nitrification under aerobic condition, which was highly dependent on dissolve oxygen (DO). Compared to other traditional mechanical aeration methods such as brush aeration and blast aeration, the water-dropping rotating aeration supplied DO at a level of $5.15 \pm 0.05 \mathrm{mg} / \mathrm{L}$ in the WDSRBC units (Table 2), achieving higher oxygen transfer capacity and lower ammonia effluent with low energy consumption. 


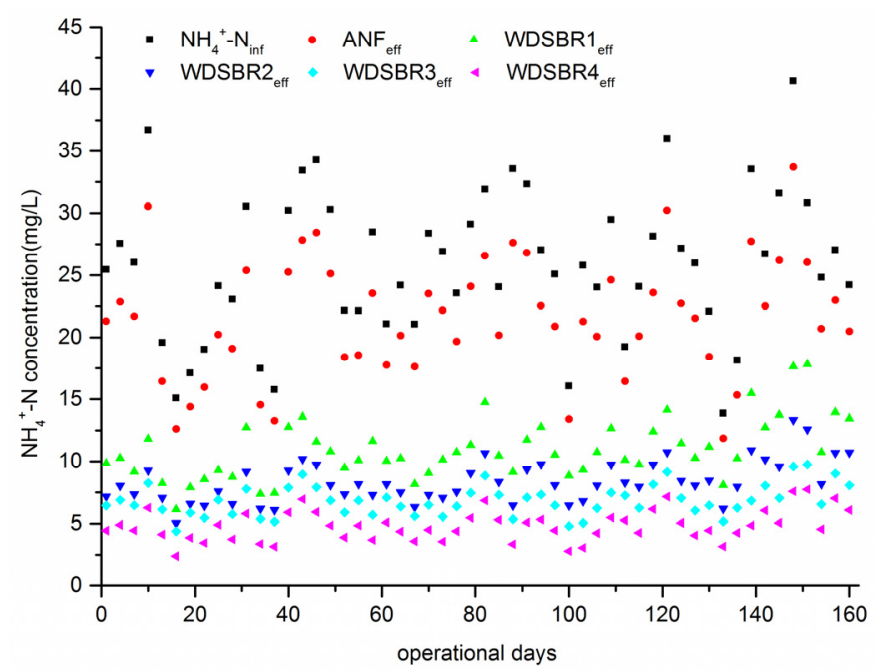

Figure 4. Influent and effluent of $\mathrm{NH}_{4}{ }^{+}-\mathrm{N}$ concentration throughout the whole operation.

The distributions of TN, ammonia, nitrate, and nitrite in each unit of the system are shown in Figure 5. It was observed that ammonia was nitrified in the WDSRBC units and approximately $62.3 \%$ of ammonia was found to be converted into nitrate. The nitrogen compound in the effluent mainly existed in the form of nitrate $(12.6 \pm 3.4 \mathrm{mg} / \mathrm{L})$ and the effluent concentration of nitrite was $0.23 \pm 0.18 \mathrm{mg} / \mathrm{L}$. The nitrite concentration was not accumulated, indicating that autotrophic denitrification might occur in the inner biofilm of the WDSRBC system [34,35]. The average TN removal efficiency in the ANF-WDSRBC system was $54.5 \% \pm 3.9 \%$ (Table 2 ), which was similar to previous reports for AT-MBR system treating digested domestic wastewater [7]. The reduction of TN might be attributed to the denitrifier in the ANF. In addition, denitrification might partially occur in the WDSRBC. These results were subject to confirmation by Illumina-MiSeq sequencing analysis.

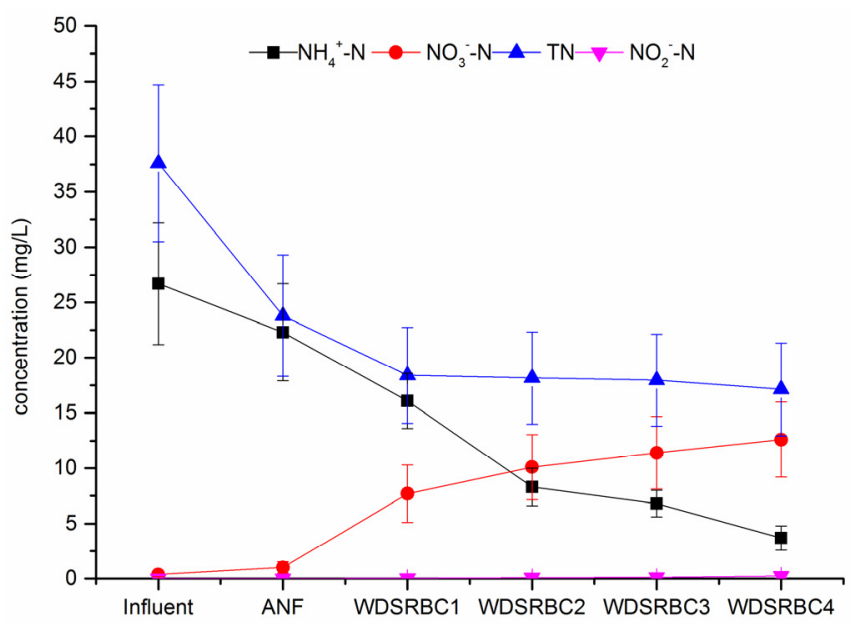

Figure 5. Nitrogen transformation in the ANF-WDSRBC system.

In order to better evaluate the performance of the ANF-WDSRBC system, the treatment efficiency of this system was compared with other post-treatment systems. The summary of comparison is shown in Table 3. Remarkably, different system configurations entailed variations of system performance. Gao et al. [7] used the AT-MBR system to treat digested domestic wastewater with a total HRT of $8 \mathrm{~h}$, reaching $87 \%$ of COD removal, $91 \%$ of $\mathrm{NH}_{4}{ }^{+}-\mathrm{N}$ removal, and $58 \%$ of $\mathrm{TN}$ removal. Even though the AT-MBR system found to have the best performance among these systems, the energy consumption of the AT-MBR system was significantly higher than others. On the other hand, ANF-WDSRBC, 
which requires lower energy consumption, showed similar $\mathrm{NH}_{4}{ }^{+}-\mathrm{N}$ and $\mathrm{TN}$ removal efficiencies to the AT-MBR system. Although the COD removal efficiency of the ANF-WDSRBC system was lower than the AT-MBR system, the effluent COD concentration was at a low level of $35.0 \pm 7.7 \mathrm{mg} / \mathrm{L}$. In addition, the $\mathrm{NH}_{4}{ }^{+}-\mathrm{N}$ and TN removal efficiencies of the ANF-WDSRBC system were higher than those in CW, ABR-WDASB, and AFB system. That might be explained that the ANF-WDSRBC system combined the advantages of WDASB and RBC to enhance oxygen transfer capability and nitrification processing via water-dropping gravity rotation. Consequently, based on a balance between the treatment efficiency and energy consumption, the ANF-WDSRBC system was a relatively better alternative option of post-treatment.

Table 3. Comparison of the performance of representative post-treatment systems in terms of COD removal, ammonia removal, $\mathrm{TN}$ removal, and energy consumption.

\begin{tabular}{ccccccccc}
\hline Post-Treatment & $\begin{array}{c}\mathbf{C O D}_{\text {inf }} \\
(\mathbf{m g} / \mathbf{L})\end{array}$ & $\begin{array}{c}\text { Removal } \\
\mathbf{( \% )}\end{array}$ & $\begin{array}{c}\mathbf{N H}_{\mathbf{4}}{ }^{+}-\mathbf{N}_{\text {inf }} \\
(\mathbf{m g} / \mathbf{L})\end{array}$ & $\begin{array}{c}\text { Removal } \\
\mathbf{( \% )}\end{array}$ & $\begin{array}{c}\mathbf{T N}_{\text {inf }} \\
(\mathbf{m g} / \mathbf{L})\end{array}$ & $\begin{array}{c}\text { Removal } \\
\mathbf{( \% )}\end{array}$ & $\begin{array}{c}\text { Energy } \\
\text { Consumption }\end{array}$ & Reference \\
\hline AT-MBR & $186.8 \pm 10.4$ & 87 & $44.1 \pm 4.8$ & 91 & 58.8 & 58 & Higher & {$[7]$} \\
AFB & $103 \pm 25$ & 47.6 & - & - & $38 \pm 6$ & 21 & High & {$[31]$} \\
ABR-WDASB & 167 & 53.3 & 22.3 & 50 & 22.3 & 33 & Low & {$[4]$} \\
CW & $175 \pm 89$ & 72 & $27.9 \pm 14.0$ & 38 & $55 \pm 9.5$ & 32 & Lower & {$[30]$} \\
ANF-WDSRBC & $91.4 \pm 21.0$ & $61.4 \pm 4.3$ & $26.7 \pm 5.5$ & $86.1 \pm 3.7$ & $37.6 \pm 7.1$ & $54.5 \pm 3.9$ & Low & This study \\
\hline
\end{tabular}

Where, AT anoxic tank; MBR aerobic membrane bioreactor; AFB aerated fixed bed; ABR anoxic biofilm reactor; WDASB water-dropping aeration submerged biofilm reactor; $C W$ : constructed wetland.

\subsection{Diversity of Microbial Community in the ANF-WDSRBC System}

As the core of biological processing, the functional bacteria in each reactor of the ANF-WDSBRC system mainly determined the performance of the system including the removal of COD and nitrogen. In order to get a full understanding of the difference of bacterial communities in each unit of the ANF-WDSRBC system, Illumina-Miseq sequencing was applied to investigate the microbial consortium in ANF, WDSRBC1, WDSRBC2, WDSRBC3, and WDSRBC4, respectively. Figure 6 illustrates the relative abundance of the bacterial community at the phylum level. The bacterial community in the ANF-WDSRBC system demonstrated high diversity, 31 taxonomic categories at phyla level were summarized. The top four bacterial phyla (Proteobacteria, Bacteroidetes, Firmicutes, and Chloroflexi) accounted for $83.1 \%, 87.3 \%, 85.3 \%, 77.8 \%$, and $85.4 \%$ of total bacteria in ANF, WDSRBC1, WDSRBC2, WDSRBC3, and WDSRBC4, respectively. Despite the same major phyla in these units, the relative abundances of bacteria were significantly different. The phylum Proteobacteria predominated in the WDSRBC units $(52.7 \%-63.3 \%)$ of the system, while it showed a lower relative abundance in the ANF unit $(39.2 \%)$. These results were similar to the previous study of bacterial communities in activated sludge, in which the phylum Proteobacteria accounted for 36\%-65\% of the total effective bacterial sequences [26]. Different with Proteobacteria, the dominant phylum Chloroflexi was much higher in ANF $(16.7 \%)$ than in WDSRBC units $(4.9 \%-5.3 \%)$. Interestingly, the relative abundance of the Gram-negative Gemmatimonadetes was higher in WDSRBC units $(1.9 \%-6.4 \%)$ than in ANF $(0.92 \%)$, this is quite different from a previous study which reported that the phylum Gemmatimonadetes accounted for $0.49 \%-0.51 \%$ of the total bacteria in activated sludge [36]. These differences were likely due to the environment factors including dissolved oxygen concentration, the concentrations of organic matter, and nutrients. Different relative abundance of bacterial community in the ANF and WDSRBC units might explain the performance of these units in decentralized domestic wastewater treatment. Meanwhile, other phyla in the system might also provide the potential pathways for COD and nitrogen removal, including Acidobacteria, Actinobacteria, Chlorobi, Planctomycetes, Verrucomicrobia, Nitrospirae, and so on [26,37,38]. 


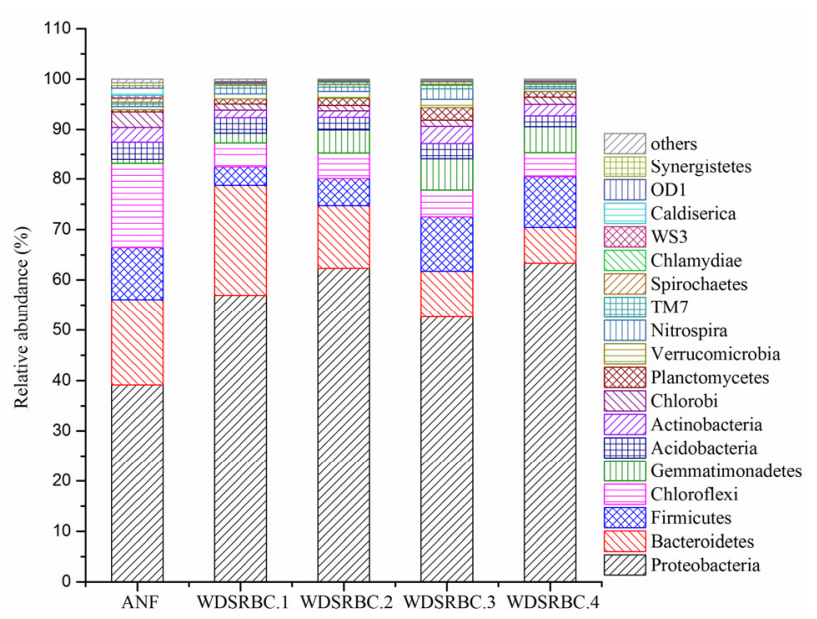

Figure 6. Bacterial community structures in units at phylum level.

In order to further get a deeper insight into the bacterial community in the ANF-WDSRBC system, the phylogenetic classification of bacterial sequences from the samples at class level was presented in Figure 7. At the class level, the difference in the bacterial community of ANF and WDSRBC units was significantly distinct. The top two classes in ANF were Betaproteobacteria (16.1\%) and Anaerolineae $(14.5 \%)$, whereas the predominant classes in WDSRBC units were Betaproteobacteria $(22.5 \%-33.5 \%)$ and Gammaproteobacteria (13.3\%-16.2\%). In addition, the relative abundance of the class Bacilli remarkably increased from $1.83 \%$ in WDSRBC1 to $8.32 \%$ in WDSRBC4. On the contrary, the relative abundances of the classes Sphingobacteria, Bacteroidia, and Flavobacteria gradually decreased along the flowpath of WDSRBC units. Just like at phylum level, the distribution of some classes might also depend on the composition of wastewater, organic loading, and DO concentration in each unit of the system [26].

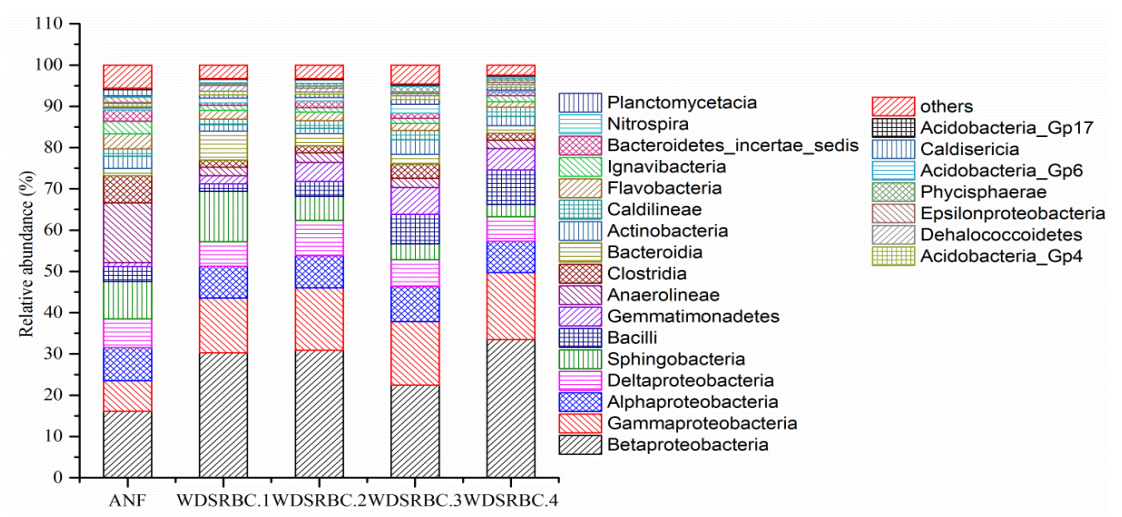

Figure 7. Bacterial community structures in units at class level.

At a genus level, 18 representative genera identified in ANF and WDSRBC units were shown in Table 4. Among these genera, the detected nitrifying bacteria in WDSRBC units mainly included those from genera Nitrosomonas $(0.23 \%-1.59 \%)$, Nitrosospira $(2.59 \%-4.01 \%)$, Bacillus $(0.73 \%-4.29 \%)$, and Nitrospira $(0.96 \%-2.39 \%)$. In this study, high ammonia removal efficiency in the WDSRBC unit might be due to the leading role of these main nitrifying bacteria. Unlike the traditional method which misses the minor functional bacterial community, the minor genera Nitrobacter $(0.03 \%-0.10 \%)$, Pseudomonas $(0.05 \%-0.20 \%)$, and Luteimonas $(0.03 \%-0.14 \%)$ were also detected by high-throughput Illumina-Miseq sequencing. These minor genera might coexist and contribute considerably to the nitrification of the system process. Even though previous study reported that most heterotrophic bacteria were denitrifers [39-41], the denitrifiers in ANF mainly included the bacteria from genera 
Thiobacillus (2.01\%), Thauera (1.02\%), and Bacillus (2.43\%). The genus Thauera belonging to the class Betaproteobacteria was also detected in the activated sludge system [33]. Windey et al. reported that Bacillus played important roles in denitrification [42]. In our study, TN removal efficiency in the ANF was much higher than in WDSRBC (Figure 5), indicating that these genera might be key contributors to converting nitrate to nitrogen gas in ANF unit. In addition, based on the Illumina-Miseq sequencing platform, the minor genus Nitratifractor $(0.02 \%)$, which likely participated in denitrification processes, was identified only in the ANF unit. Interestingly, the denitrification genus Flavobacterium $(0.18 \%-0.58 \%)$ was detected in WDSRBC units, which was also identified in the aerobic tanker [43]. It indicated that some bacteria of the genus Flavobacterium probably had the dentrification capability under aerobic conditions to participate in TN removal.

Table 4. The relative abundance of dominant bacterial populations at genus level.

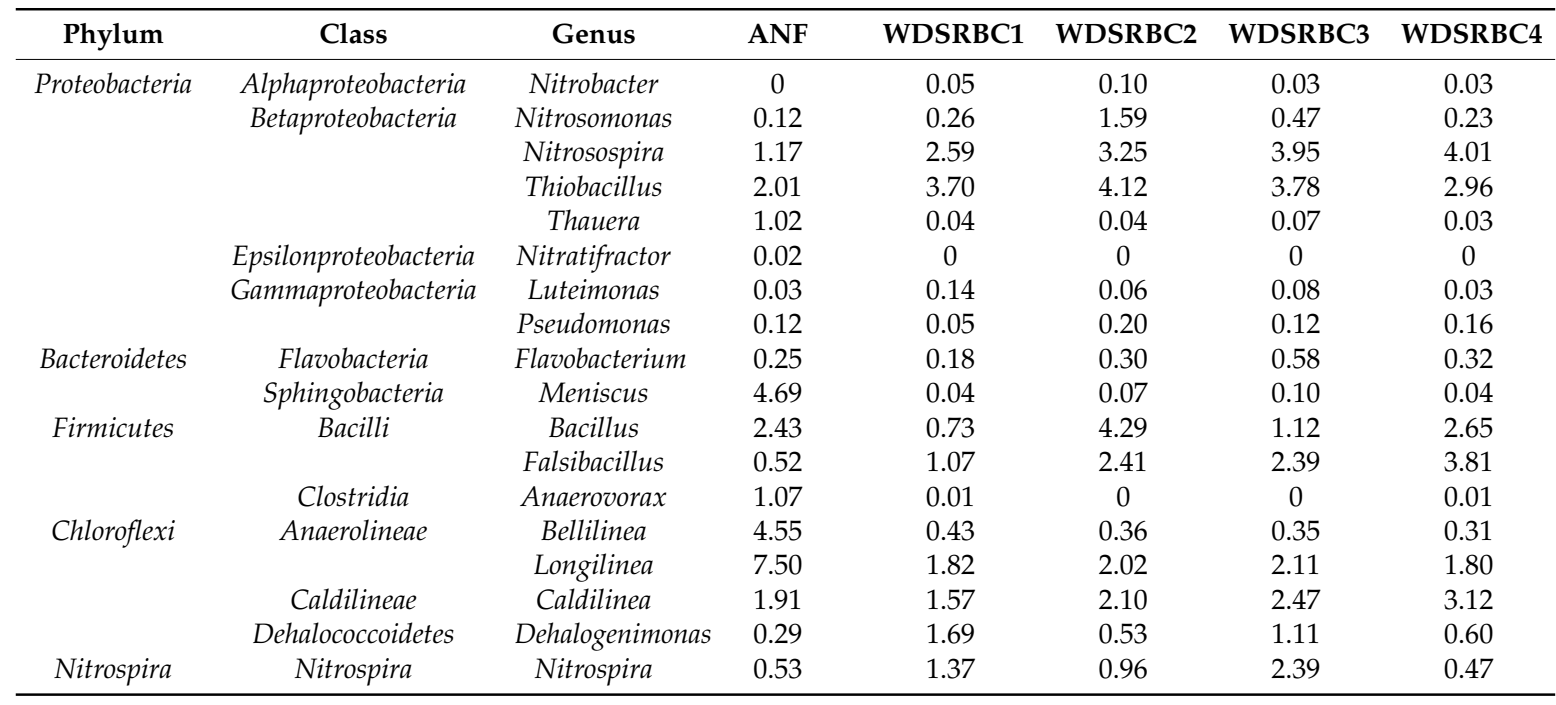

The other representative genera Meniscus (4.69\%), Longilinea (7.5\%), Bellilinea (4.55\%) were typical identified in the ANF unit. Members of these genera may be correlating to both carbohydrate and amino acid degradation $[44,45]$. This might partially explain the reason for COD removal in ANF units. The genus Caldilinea $(1.57 \%-3.12 \%)$ was detected in the WDSRBC unit, which may affect the formation of sludge flocs [46]. Taken together, the microbial communities coexisted in each unit ensured the desired performance of ANF-WDSRBC system.

\section{Conclusions}

The combined ANF-WDSRBC system was used to treat decentralized domestic wastewater under continuous-flow operation with an HRT of $8.8 \mathrm{~h}$ and reflux ratio of 1:1. The average removal efficiencies of $61.4 \% \pm 4.3 \%, 86.1 \% \pm 3.7 \%$, and $54.5 \% \pm 3.9 \%$ for $\mathrm{COD}, \mathrm{NH}_{4}{ }^{+}-\mathrm{N}$, and $\mathrm{TN}$ were achieved by the system. Compared to some representative post-treatment systems, the ANF-WDSRBC showed a relatively better performance with low energy consumption. Deeper sequencing results indicated that Proteobacteria, Bacteroidetes, Firmicutes, and Chloroflexi were the predominant phyla in the system. The genera Nitrosomonas, Nitrosospira, Bacillus, and Nitrospira in the WDSRBC units played vital roles in nitrification, whereas Longilinea, Bellilinea, Thiobacillus, and Thauera in the ANF unit were the main genera to participate in denitrification and organic matter degradation. Therefore, the ANF-WDSRBC system is a viable option for decentralized domestic wastewater post-treatment.

Acknowledgments: This research was supported by China National Water Pollution Control and Management Technology Major Projects (2012ZX07101-005). The authors would like to thank the editors and the anonymous reviewers for editing and review. 
Author Contributions: Juanhong Li and Xiwu Lu conceived and designed the experiments; analyzed the data; and wrote the paper.

Conflicts of Interest: The authors declare no conflicts of interest.

\section{References}

1. Libralato, G.; Ghirardini, A.V.; Avezzù, F. To centralise or to decentralise: An overview of the most recent trends in wastewater treatment management. J. Environ. Manag. 2012, 94, 61-68. [CrossRef] [PubMed]

2. López-López, A.; Albarrán-Rivas, M.G.; Hernández-Mena, L.; León-Becerril, E. An assessment of an anaerobic filter packed with a low-cost material for treating domestic wastewater. Environ. Technol. 2013, 34, 1151-1159. [CrossRef] [PubMed]

3. Smith, A.L.; Skerlos, S.J.; Raskin, L. Psychrophilic anaerobic membrane bioreactor treatment of domestic wastewater. Water Res. 2013, 47, 1655-1665. [CrossRef] [PubMed]

4. Wu, Y.; Zhu, W.; Lu, X. Identifying key parameters in a novel multistep bio-ecological wastewater treatment process for rural areas. Ecol. Eng. 2013, 61, 166-173. [CrossRef]

5. Feng, H.; Hu, L.; Mahmood, Q.; Qiu, C.; Fang, C.; Shen, D. Anaerobic domestic wastewater treatment with bamboo carrier anaerobic baffled reactor. Int. Biodeterior. Biodegrad. 2008, 62, 232-238. [CrossRef]

6. Gao, D.-W.; An, R.; Tao, Y.; Li, J.; Li, X.-X.; Ren, N.-Q. Simultaneous methane production and wastewater reuse by a membrane-based process: Evaluation with raw domestic wastewater. J. Hazard. Mater. 2011, 186, 383-389. [CrossRef] [PubMed]

7. Gao, D.-W.; Tao, Y.; An, R. Digested sewage treatment using membrane-based process at different hydraulic retention times. Desalination 2012, 286, 187-192. [CrossRef]

8. McCarty, P.L.; Bae, J.; Kim, J. Domestic wastewater treatment as a net energy producer-Can this be achieved? Environ. Sci. Technol. 2011, 45, 7100-7106. [CrossRef] [PubMed]

9. Andersen, J.H.; Fossing, H.; Hansen, J.W.; Manscher, O.H.; Murray, C.; Petersen, D.L. Nitrogen inputs from agriculture: Towards better assessments of eutrophication status in marine waters. Ambio 2014, 43, 906-913. [CrossRef] [PubMed]

10. Abouelela, S.I.; Fawzy, M.E.; Elgendy, A.S. Potential of using biological aerated filter as a post treatment for municipal wastewater. Ecol. Eng. 2015, 84, 53-57. [CrossRef]

11. Bastos, R.; Calijuri, M.; Bevilacqua, P.; Rios, E.; Dias, E.; Capelete, B.; Magalhães, T. Post-treatment of UASB reactor effluent in waste stabilization ponds and in horizontal flow constructed wetlands: A comparative study in pilot scale in southeast brazil. Water Sci. Technol. 2010, 61, 995-1002. [CrossRef] [PubMed]

12. Elkhateeb, M.A.; Alherrawy, A.Z.; Kamel, M.M.; Elgohary, F.A. Use of wetlands as post-treatment of anaerobically treated effluent. Desalination 2009, 245, 50-59. [CrossRef]

13. Yu, R.; Wu, Q.; Lu, X. Constructed wetland in a compact rural domestic wastewater treatment system for nutrient removal. Environ. Eng. Sci. 2012, 29, 751-757. [CrossRef]

14. Hiras, D.N.; Manariotis, I.D.; Grigoropoulos, S.G. Organic and nitrogen removal in a two-stage rotating biological contactor treating municipal wastewater. Bioresour. Technol. 2004, 93, 91-98. [CrossRef] [PubMed]

15. Peng, X.; Guo, F.; Ju, F.; Zhang, T. Shifts in the microbial community, nitrifiers and denitrifiers in the biofilm in a full-scale rotating biological contactor. Environ. Sci. Technol. 2014, 48, 8044-8052. [CrossRef] [PubMed]

16. Courtens, E.; Boon, N.; De Clippeleir, H.; Berckmoes, K.; Mosquera, M.; Seuntjens, D.; Vlaeminck, S.E. Control of nitratation in an oxygen-limited autotrophic nitrification/denitrification rotating biological contactor through disc immersion level variation. Bioresour. Technol. 2014, 155, 182-188. [CrossRef] [PubMed]

17. Tawfik, A.; Klapwijk, A.; Elgohary, F.A.; Lettinga, G. Potentials of using a rotating biological contactor (RBC) for post-treatment of anaerobically pre-treated domestic wastewater. Biochem. Eng. J. 2005, 25, 89-98. [CrossRef]

18. Malachova, K.; Rybkova, Z.; Sezimova, H.; Cerven, J.; Novotny, C. Biodegradation and detoxification potential of rotating biological contactor (RBC) with irpex lacteus for remediation of dye-containing wastewater. Water Res. 2013, 47, 7143-7148. [CrossRef] [PubMed]

19. Castillo, E.; Vergara, M.; Moreno, Y. Landfill leachate treatment using a rotating biological contactor and an upward-flow anaerobic sludge bed reactor. Waste Manag. 2007, 27, 720-726. [CrossRef] [PubMed]

20. Hassard, F.; Biddle, J.; Cartmell, E.; Jefferson, B.; Tyrrel, S.F.; Stephenson, T. Rotating biological contactors for wastewater treatment-A review. Process Saf. Environ. 2015, 94, 285-306. [CrossRef] 
21. Fountoulakis, M.S.; Terzakis, S.; Chatzinotas, A.; Brix, H.; Kalogerakis, N.; Manios, T. Pilot-scale comparison of constructed wetlands operated under high hydraulic loading rates and attached biofilm reactors for domestic wastewater treatment. Sci. Total Environ. 2009, 407, 2996-3003. [CrossRef] [PubMed]

22. Burgara-Montero, O.; El-Baz, A.A.; Ponce-Ortega, J.M.; El-Halwagi, M.M. Optimal design of a distributed treatment system for increasing dissolved oxygen in watersheds through self-rotating discs. Sustain. Chem. Eng. 2013, 1, 1267-1279. [CrossRef]

23. EI Monayerie, D.S.; Atta, N.N.; EI Din, D.S.; Daif, S. Modeling of oxygen transfer in self-rotating biological contactors (SRBC). In Proceeding of the Sixteenth International Water Technology Conference (16th IWTC), Istanbul, Turkey, 7-10 May 2012.

24. Chen, Z.; Wen, Q.; Wang, J.; Li, F. Simultaneous removal of carbon and nitrogen from municipal-type synthetic wastewater using net-like rotating biological contactor (NRBC). Process Biochem. 2006, 41, 2468-2472. [CrossRef]

25. Sayess, R.R.; Saikaly, P.E.; El-Fadel, M.; Li, D.; Semerjian, L. Reactor performance in terms of COD and nitrogen removal and bacterial community structure of a three-stage rotating bioelectrochemical contactor. Water Res. 2013, 47, 881-894. [CrossRef] [PubMed]

26. Zhang, T.; Shao, M.; Ye, L. 454 pyrosequencing reveals bacterial diversity of activated sludge from 14 sewage treatment plants. ISME J. 2012, 6, 1137-1147. [CrossRef] [PubMed]

27. Briones, A.; Raskin, L. Diversity and dynamics of microbial communities in engineered environments and their implications for process stability. Curr. Opin. Biotech. 2003, 14, 270-276. [CrossRef]

28. American Public Health Association (APHA). Standard Methods for the Examination of Water and Waste Water; American Public Health Association: Washington, DC, USA, 2005.

29. Chiou, R.J.; Ouyang, C.F. The effect of recycle ratio on nitrogen removal in the combined pre-denitrification/nitrification biofilter system. J. Chem. Technol. Biotechnol. 2001, 76, 559-564. [CrossRef]

30. Barros, P.; Ruiz, I.; Soto, M. Performance of an anaerobic digester-constructed wetland system for a small community. Ecol. Eng. 2008, 33, 142-149. [CrossRef]

31. Sumino, H.; Takahashi, M.; Yamaguchi, T.; Abe, K.; Araki, N.; Yamazaki, S.; Shimozaki, S.; Nagano, A.; Nishio, N. Feasibility study of a pilot-scale sewage treatment system combining an up-flow anaerobic sludge blanket (UASB) and an aerated fixed bed (AFB) reactor at ambient temperature. Bioresour. Technol. 2007, 98, 177-182. [CrossRef] [PubMed]

32. Singh, V.; Mittal, A.K. Characterization of biofilm of a rotating biological contactor treating synthetic wastewater. Water Sci. Technol. 2012, 66, 429-437. [CrossRef] [PubMed]

33. Yadav, T.C.; Khardenavis, A.A.; Kapley, A. Shifts in microbial community in response to dissolved oxygen levels in activated sludge. Bioresour. Technol. 2014, 165, 257-264. [CrossRef] [PubMed]

34. Gupta, A.; Gupta, S.K. Simultaneous carbon and nitrogen removal from high strength domestic wastewater in an aerobic RBC biofilm. Water Res. 2001, 35, 1714-1722. [CrossRef]

35. Blackburne, R.; Yuan, Z.; Keller, J. Demonstration of nitrogen removal via nitrite in a sequencing batch reactor treating domestic wastewater. Water Res. 2008, 42, 2166-2176. [CrossRef] [PubMed]

36. Chiellini, C.; Munz, G.; Petroni, G.; Lubello, C.; Mori, G.; Verni, F.; Vannini, C. Characterization and comparison of bacterial communities selected in conventional activated sludge and membrane bioreactor pilot plants: A focus on nitrospira and planctomycetes bacterial phyla. Curr. Microbiol. 2013, 67, 77-90. [CrossRef] [PubMed]

37. Pizzetti, I.; Gobet, A.; Fuchs, B.M.; Amann, R.; Fazi, S. Abundance and diversity of planctomycetes in a tyrrhenian coastal system of central italy. Aquat. Microb. Ecol. 2011, 65, 129-141. [CrossRef]

38. Zumft, W.G. Cell biology and molecular basis of denitrification. Microbiol. Mol. Biol. Rev. 1997, 61, 533-616. [PubMed]

39. Wang, X.; Hu, M.; Xia, Y.; Wen, X.; Ding, K. Pyrosequencing analysis of bacterial diversity in 14 wastewater treatment systems in China. Appl. Environ. Microb. 2012, 78, 7042-7047. [CrossRef] [PubMed]

40. Ye, L.; Shao, M.; Zhang, T.; Tong, A.H.Y.; Lok, S. Analysis of the bacterial community in a laboratory-scale nitrification reactor and a wastewater treatment plant by 454-pyrosequencing. Water Res. 2011, 45, 4390-4398. [CrossRef] [PubMed]

41. Yoon, D.-N.; Park, S.-J.; Kim, S.-J.; Jeon, C.O.; Chae, J.-C.; Rhee, S.-K. Isolation, characterization, and abundance of filamentous members of caldilineae in activated sludge. J. Microbiol. 2010, 48, 275-283. [CrossRef] [PubMed] 
42. Windey, K.; De Bo, I.; Verstraete, W. Oxygen-limited autotrophic nitrification-denitrification (OLAND) in a rotating biological contactor treating high-salinity wastewater. Water Res. 2005, 39, 4512-4520. [CrossRef] [PubMed]

43. Ducey, T.F.; Vanotti, M.B.; Shriner, A.D.; Szogi, A.A.; Ellison, A.Q. Characterization of a microbial community capable of nitrification at cold temperature. Bioresour. Technol. 2010, 101, 491-500. [CrossRef] [PubMed]

44. Chan, Y.; Li, A.; Gopalakrishnan, S.; Shin, P.K.S.; Wu, R.S.S.; Pointing, S.B.; Chiu, J.M.Y. Interactive effects of hypoxia and polybrominated diphenyl ethers (PBDES) on microbial community assembly in surface marine sediments. Mar. Pollut. Bull. 2014, 85, 400-409. [CrossRef] [PubMed]

45. Yamada, T.; Sekiguchi, Y. Cultivation of uncultured Chloroflexi subphyla: Significance and ecophysiology of formary uncultured Chloroflexi ‘subphylum I' with natural and biotechnological relevance. Microbes Environ. 2009, 24, 205-216. [CrossRef] [PubMed]

46. Jin, P.; Wang, X.; Wang, X.; Ngo, H.H.; Jin, X. A new step aeration approach towards the improvement of nitrogen removal in a full scale carrousel oxidation ditch. Bioresour. Technol. 2015, 198, 23-30. [CrossRef] [PubMed]

(c) 2017 by the authors. Licensee MDPI, Basel, Switzerland. This article is an open access article distributed under the terms and conditions of the Creative Commons Attribution (CC BY) license (http:/ / creativecommons.org/licenses/by/4.0/). 